\title{
Differential regulation of motility and immune synapses by CD28/ CTLA-4 costimulation in effector and regulatory $T$ cells
}

\author{
Nahzli Dilek ${ }^{1,2}$, Nicolas Poirier ${ }^{1,2}$, Philippe Hulin ${ }^{1,2}$, Gilles Blancho ${ }^{1,2}$, Bernard Vanhove ${ }^{1,2^{*}}$ \\ From 7th European Workshop on Immune-Mediated Inflammatory Diseases \\ Noordwijk aan Zee, the Netherlands. 28-30 November 2012
}

\section{Background}

We have previously shown that antagonist anti-CD28 antibodies block CD28/CD80-86 costimulation without perturbation of the CTLA-4/CD80-86 inhibitory pathway and favor tolerance induction by increasing Treg suppression in a CTLA-4 dependent manner. Since CTLA-4 is transducing signals that block the TCR-STOP signal, described to allow for $\mathrm{T}$ cell arrest and formation of immune synapses, we hypothesized that CTLA-4 might play a major role in the mechanism of action of antiCD28 antibodies by regulating $\mathrm{T}$ cell motility and synapses formation.

\section{Materials, methods and results}

Here, we generated human $\mathrm{CD} 4^{+} \mathrm{CD} 25^{+} \mathrm{CD} 127^{+}$Teff and $\mathrm{CD} 44^{+} \mathrm{CD} 25^{\text {high }} \mathrm{CD} 127^{\text {low }} \mathrm{Foxp}^{+}$Treg cell lines and analyzed their behavior in contact with cognate APCs by live-cell dynamic microscopy in the presence of CD28 and CTLA-4 antagonists. CD28 blockade prevented formation of stable contacts between Teff and APCs $(11.93 \pm 1.175$ vs $4.167 \pm 1.191 \mathrm{~min} ; \mathrm{p}<0.05)$, increased Teff mobility $(100.5 \pm 6.032$ vs $204.8 \pm 17.54$ $\mu \mathrm{m} ; \mathrm{p}<0.0001)$ and decreased cell activation measured by calcium flux $(0.377 \pm 0.028$ vs $0.154 \pm 0.024$ calcium peaks/min; $\mathrm{p}<0.0001)$. In contrast, CD28 antagonists enhanced Treg/APC contacts $(5.057 \pm 0.866$ vs $13.81 \pm$ $1.104 \mathrm{~min} ; \mathrm{p}<0.0001)$ and increased calcium flux $(0.486 \pm$ 0.048 vs $0.677 \pm 0.06$ calcium peaks $/$ min; $p<0.05$ ), resulting in an increase of Treg activation. The simultaneous blockade of CTLA-4 with antibodies or of CD80/86 with CTLA4Ig reversed some of these effects: it restored the STOP signal and reduced motility/velocity in Teff whereas

${ }^{1}$ Institute of Transplantation Urology Nephrology, University of Nantes, INSERM UMR 1064, Nantes, France Effimune, Nantes, France

Full list of author information is available at the end of the article it increased velocity in Treg and abolished Treg/APC contacts.

\section{Conclusion}

Our data shed light on the role of CD28 and CTLA-4 that act as a rheostat to differentially control Teff and Treg function and clarify the observations that selective CD28-blockade but not CD80/86 blockade reinforces Treg cell suppression in vitro.

\section{Author details}

${ }^{1}$ Institute of Transplantation Urology Nephrology, University of Nantes, INSERM UMR 1064, Nantes, France Effimune, Nantes, France. ${ }^{2}$ IMPACT INSERM platform, Nantes, France.

Published: 28 November 2012

\section{doi:10.1186/1479-5876-10-S3-P6}

Cite this article as: Dilek et al:: Differential regulation of motility and immune synapses by CD28/ CTLA-4 costimulation in effector and regulatory T cells. Journal of Translational Medicine 2012 10(Suppl 3):P6.

Submit your next manuscript to BioMed Central and take full advantage of:

- Convenient online submission

- Thorough peer review

- No space constraints or color figure charges

- Immediate publication on acceptance

- Inclusion in PubMed, CAS, Scopus and Google Scholar

- Research which is freely available for redistribution
C Biomed Central

(0) 2012 Dilek et al; licensee BioMed Central Ltd. This is an Open Access article distributed under the terms of the Creative Commons Attribution License (http://creativecommons.org/licenses/by/2.0), which permits unrestricted use, distribution, and reproduction in any medium, provided the original work is properly cited. 